\title{
Multiple Positions towards the Modernization of Arab-Islamic Heritage in the Contemporary World
}

\author{
${ }^{1}$ Prof. Dr. Salahuddin Mohd. Shamsuddin, ${ }^{2}$ Prof. Dr. Zuraidah binti Mohammad \\ Don \\ Dept. of Arabic \& Middle Eastern Languages, Faculty of Languages and Linguistics, University of Malaya, \\ 50603 Kuala Lumpur, Malaysia \\ Dean: Faculty of Languages and Linguistics, University of Malaya, 50603 Kuala Lumpur, Malaysia
}

\begin{abstract}
It is true that originality is not that the man remains in living alone, but the originality is to evacuate the idea with the ideas of others, "The lion is not only several digestible sheep", but the renewal or development of heritage does not mean that the search for the originality or individuality turns to the romantic slogan, which sanctifies all the new for the sake of itself and looks at the values of things in their ages or affiliation to this age.

Undoubtedly, the response to the spirit of the times is essential in the concept of development, but the romantic mantras: the (self) and (zeitgeist) without realizing the act of the past and its importance in directing the contemporary age is unacceptable.

The renewal or development is not to repeat the old thinking or use an old drum always, but it is related to the greatness of heritage or culture needs the humanitarian effectiveness to highlight it, which is our responsibility. The recognition by all over the world cannot be without the inherent power within our message, which cannot be obtained from abroad. The renewal is the formation of a general cosmic perspective strikes in the depths of the heritage with its roots, overlooking with the branches of its present at all of its dimensions and requirements.
\end{abstract}

Keywords: 1. Modernization of religious heritage, 2. Imitation, 3. Innovation, 4. Innovators, 5. Revolution.

\section{Movement for the Revival of Islamic Heritage (A study and investigation)}

Arab-Islamic heritage which concerns us here includes a wealth of books and manuscripts in the different fields left by Arab-Islamic creativity in the era of its renaissance. A lot of those books and manuscripts have been lost by the exhaust of time, but many of them remained. Some of them has been revived and republished partially, which inspired the confidence in the souls... For a while some of those who proved their footsteps on the (bridge of the place) Western civilization liked them. They saw that the Arab world has gone in the way of this civilization, which is called by the people Western civilization, which is only a human civilization derived its bases from many humanitarian civilizations including Arab-Islamic civilization, and Eastern and Western peoples had contributed and still contribute to enrich this human civilization... Some others still emphasize the need to return to their heritage to revive the contemporary self on the basis of its guidance by making a connection with it. They did not stop their calling for the revival of heritage, but they started actually doing their best to discover its secrets. They reopened the writing and authoring what was in the heritage of thirteen centuries as they could. Some of them (writings of Heritage) have achieved and explained to be suitable for the Perceptions of modern era and some others are as they were.

Those manuscripts that have been republished were related to the language, literature, history, religious sciences, dogmatic theology and others. Although the manuscripts of the heritage were distributed among the cities of the Islamic world and leaked to some Western cities, somehow the movement adopted in its activities three centers of the most important Islamic capitals, were full filled with the manuscripts during the nineteenth century, namely: Cairo, Istanbul and Hyderabad Deccan.

The scientists and qualified investigators carried this responsibility. They were capable in the sciences of Arabic language and Islamic knowledge. As well as they had a bid enthusiasm and perseverance to uphold the glory of Islam and Arabism. The most important of those distinguished people were Sheikh Abu al-Wafã Nașr Al-Hūrinī, Aḥmad Fāris Shidyāq, and Muhammad Maḥmūd Al-Sanqaty̆, who was chosen by Sultan 'Abdul Hamid to go to Spain to research in its different libraries were full filled with Arabic and Islamic books and manuscripts. Ibrahim Muwaylahy also was one of the founders of the "Association of knowledge" and its printing press, which had a great role in the revival movement. Those investigators and their ilk were supported by the leaders of thought who preached the revival movement and called to it and supported it by their effort and wealth. 
These and those motivated by the desire rushed to discover the treasures of the heritage, while some deviated to escape from the heritage and the past, they thought that their civilization has been (bankrupted and disappeared, even there is no way to return it back or revive). Hence many thinkers in Arab and Muslim countries turned towards Western civilization as it is the prevailing (civilization of today) or it must prevail (1). At the same time some others - skeptical Arabs and Orientalists also - stayed in doubt about the feasibility of this revival and decided that it is (impossible) to revive a dead thing.

An American Orientalist J. Von Grunebaum - for example - has a dissenting opinion against the decision taken by his colleague H. R. Hub in this regard that the Heritage Revival was a Revival of selfconfidence and that was a (reformation in return) means the reformation inside the Arab front to face the West. $\mathrm{He}$ argues that this interest in reviving the heritage represents the phenomenon of fear of Arabs and Muslims that the (West will swallow them) or the (West will throw them). Therefore, they tried to imitate the west, melting in their culture. This phenomenon is a characteristic of every society (knocked down by the retardation) and went to repeat itself through the history, but it is always a partial rebuilding, which suits the desire of the Arab world in replacing that was done by them in the past with what it should be now.

As Heritage Revival Movement faced the hardship of some intellectuals in their own backyard either for futility (temporal bridge) - in their view - to cross towards the progress or for they prefer the spatial crossing towards the West. As Zaki Najib Mahmūd - for example - accepts that he began his intellectual life (fanatically severe) for the view that there is no hope for the contemporary intellectual life without a break with our relation to the heritage and living with those people, they live in this era having the knowledge and civilization... Then Zaki Najib changed his opinion and others also. Some of them sided with the West... Some of them walked with the heritage...some of them were against the heritage... It seemed that riders of Arab intellectual movement in the twentieth century lived as the strangers. Their belongings were lacking the contemporary cultural and intellectual goods in the stages of Receiving, configuration and vulnerability. So 'Abbas Mahmūd Al-'Aqqād (accepts the whole heritage and the entire West), as he thinks that it is possible to combine them. Sheikh Muhammad 'Abduh accepts (the whole heritage and some of the West)... While the verse reflected the opposite when Taha Hussein accepted (the all West and some of the heritage) and Tawfiq al-Hakim makes some changing in both of them and almost refuses every thing except the (amendment). (2)

We think there is no need to break with the heritage. We should call to leave the traditional understanding of the heritage, which means to be free of the sediments of heritage in our understanding of the heritage, and on the top of these sediments is the (measurement) which is used in idiosyncratic grammar, Islamic laws and dogmatic theology. The break, which is called by us, it is not a break with the heritage but with the condition of relationship with the heritage, the break, which changes us from (heritable creatures) to creatures have a heritage, which means that there are characters, and Heritage is counted as One component of their figures, The combined rectifier between them is a general character, which is character of the nation owner of the Heritage.

\section{Attempts of Muslim Scholars for the Development of Arab-Islamic Heritage}

No doubt that many attempts and huge efforts have been done by many rationalists thinkers in the East to combine and reconcile between the progress in the West and underdevelopment in the East in the both scientific fields: theoretical and applied, such as: Muḥammad Iqbāl, Muḥammad Husayn Haykal, Zaki Najib Maḥmūd, Muhammad Arkūn, Nașr Abu Zayd and many others, but we will mention here some of them to examine their positions on the issue of reviving the religious heritage of Islam.

\section{A. Muhammad Iqbāl}

The first goal and signified meaning for the renewal of religious discourse that the poet Muhammad Iqbāl wanted to give it, is to provide a mental basis to the core Islamic principles, because he believes that the religion cannot ignore the attempts for the reconciling the opposites found in the world of experience. As well as he believes that religion hardly dispenses with the explanation, and it justifies the environmental conditions in which the humanity finds itself surrounded. He supports in this context English philosopher Hoatahed in his view that the faith does not flourish only in the times of mental views.

Iqbāl was trying to convert the religion as being just a theoretical knowledge to a knowledge in agreement with the same religious experience, within the framework was prepared by (Imam Abu Hâmid alGhazāli) in the past, but this goal cannot be achieved easily. Therefore we see that Iqbāl insists on the importance of this religious experience. He believes that it is the basis of eternal truth and the balance between the intuition and mind in the life of a Muslim and it is the center of gravity for the cultural iconic building, and bright splendid civilization, which is built by Islam.

In fact, Muhammad Iqbāl did not mean to present an integrated philosophy of a distinct philosophical doctrine, but he meant what was expressed by him in the introduction to his lectures, which is the creation of a 
new building for the religious philosophy of Islam, taking into account the maxim of the philosophy of Islam, as well as the evolution happened to the human knowledge in its different environment.

It is clear from the position of Muhammad Iqbāl that he tried to formulate a philosophy of religious thought, which combines philosophical origins of Islam and the methodology of Western philosophy. He declares in the introduction to his lectures that he does not present a final drafting and final solutions for the dilemmas posed by him, because the philosophical thinking has no ending limit, and perhaps it is possible to find out more healthier views than the views are presented by him, so he believed the man must be remained in touch with what is provided by human thought getting the position about it by the criticism and investigation.

No doubt that the development of heritage cannot be done through the ready-made solutions taken from the continuous past without any changes for the adjustment according to the requirements of the new era, as well as we can not cut off our connection to our past in any way. The development of heritage can be done through the conciliation between the (constant) and (variable) as we see to a Muslim philosopher Muhammad Iqbāl that the life has two faces, the first is fixed and can not be changed, and the second is a moving variable, kaleidoscopic and unstable. The first face is the doctrine of monotheism, and the second side is the (Ijtihād): (diligence) means (the individual judgment). Islam has reconciled these two sides of the life. In one hand Islam gave us some valuable assets and principles. These principles are inclusive, comprehensive and immortal. By them we can prove our feet in this variable world. In the other hand Islam gave us the choice to develop those assets and principles, to build a beneficial healthy system through the individual judgment in the light of those immortal assets and principles, as we see that the life of the Islamic religion based on the mixing between the constant and variable. If Islam remains on this mixing, there will be a progress every moment.

We should stay here with Muhammad Iqbāl for a while, because he did not criticize the East and Eastern religious persons and Sufis by their names only, but also he marked the defects were in their thinking. It does not mean that he was ignorant about the importance of the East, as he stated in his words: (Do not hate the East, as well as, do not be away from the West, because the nature (the will of Creator: God) refers to that you should light each dark night, whether it is in the East or in the West by the light of knowledge and faith, means by the word: "every dark night" the social, cultural and political situations of ignorant human societies everywhere in the world.

He addresses the East and the West generally, calling them for some joint efforts for the advancement of humanity, says:

"The mind is a way of life to the Western people and the adoration (faith in God) is a secret of the existence for all the creatures to the Eastern people. The mind knows the truth and falsehood. The basis of adoration is proved by the mind. When the adoration walks with the mind (science), it is a sign for the creation of a new world. So you (human) have to be ready to create a new world, and use the (Love: Faith) and the (mind) i.e. (faith and science) both together to build it. (3)

The happiness of the human and humanity is inherent in the mixing of both communities: the East and the West. The nature of the East and the West has been affected by the political situation and the traditional religious slogans, therefore, the - Eastern or Western - human society is mixed with a lot of social disadvantages and shameful things, and though there are still many of the beauties and virtues. Here comes the role of leaders of the reformation in the East and the West to choose the virtues and beauties and reject the shameful elements.

Iqbāl was not an enemy of the West. Who counts him a popular enemy of the West on the basis of his critique, does not understand the purposes of his critical discourse, but we have to understand his discourse in the light of his saying:

"My eyes have cried many nights for the human being, even the secret of life evacuated in front of my eyes through the darkness. He also says:

"The power of the West is not from the exciting music and naked bodies and charming faces, as they are in their beauty like the charming roses, and exposed legs, and soft smooth skin, and atheism, as well as the progress of the West is not implied in the Latin alphabets, but this force and that progress in the West is because of the science and art. The lamps are lightened in the West by this instructive fire, (means by the warmth of the hard work and continued effort in the field of science and art) (4)

After this address, the role of matured minds comes to choose the suitable way of the success and the goodness, and the salvation, prosperity and happiness for the humanity as the whole.

Finally, we should mention that Iqbāl did not separate between Islam and the Islamic civilization. Therefore, he looks that Islamic religion can not be revived without the revival of Islamic civilization, and the revival of Islamic civilization can not be only by the link between Islamic sciences and the modern sciences, and by the combination between the heritage and contemporary era.

He thought that people's lives, over the time varies according to their perceptions of their own affairs, and that the modern science and technological development has changed a lot of social concepts to the people, so he addressed in his lectures entitled: "Reconstruction of religious thoughts in Islam". He was in his address against the Western culture, but he was not against the renewal in the East. 
Now it is clear that Iqbāl has chosen the way to create a new Islamic world through the combination between the religious sciences and modern sciences. Iqbāl says:

"Creation of a new world can be only by the new thinking, because the worlds can not be created with the stones and materials for the construction and reconstruction only", but it needs human mind, its thinking and planning.

In fact, these sciences are not Eastern or Western, but obtained by all mankind, and this fact can not be ignored that these sciences and their sources are developed by the human through his continued discoveries, hard scientific experiences and efforts caused the harness of the universe and nature.

Iqbāl believes that maintaining the fossilized originality (Conservatism) is ugly in the religious affairs as it is also blameworthy in other areas of human life. The religion reached us from Adam through the ages, if the religion is not subject to the evolution and upgrading, can not consistent with the renewable life, and Adam the father of mankind - was the first and last prophet and messenger of God, but we saw a long chain to erase and fix, such as the sequence of days and nights. Another new book being revealed after an old revealed book and a law after a law proves that the evolution does not happen in the human life only, but also occurs in the concepts of the fundamentals of Islam as well, and the laws and provisions are also changed by the developments in the different social situations. When the law of a nation loses its validity becomes abrogated, and another law similar to the previous one or better than the previous one is sent (We do not abrogate a verse or it can be forgotten, bring another one finer or similar (than the previous one).

God says: (What does God do to erase and to fix, he erases and fixes, and he has the mother of book) means he has the origin of all the originated books. It means that the sequence of erasure and fixing was continued until the complement of a religion for all mankind. In this sense, Islamic law (Shariah) is the final episode of the heavenly religions.

No doubt that Islam is a final divine message and an overarching, comprehensive and suitable system for everyone and every community, but the human life is moving towards the evolution every moment. The complement of religion in this verse: (I completed your religion and completed my benefaction and I have chosen for you Islam as a religion) does not mean that Islam is a rigid religion or has a fixed system, does not fit for the development, because the religion in this sense can not be consistent with the changes of the renewable life, because the life is moving towards upgrading, and the rigid system fails. Islam is a complete religion in the sense that it accepts the evolution and movement to be advanced, and completes all the requirements of renewable life. Islam has the authority to provide the sufficient means to build a suitable new and beautiful building for the requirements of any era, and to cover the needs of any society.

Islam believes that freedom of the individual and individual personality is essential to the survival of the society and its progress, because the productive and fruitful society does not consist without the balance between the individual solitary and its link to the society, and the individual solitary can not remain but to be a part of a social system operates under the law of the movement, such as celestial bodies that are a part of the solar system, where we see each and every one of them moves and spins in its own circle, but each and every one of them has an independent existence. If there is a loss of balance in the movement or any defect is found in the rotation the whole solar system will be spoiled, because the solar system consists of mixing power of the attraction and movement, as well as the community consists of individuals, their links to the society and serious cooperation among all of its members, and when a practical social system is generated, a unity among its members is generated by that system. The balance in the universe can not be kept without the unity, Iqbāl says:

"Everything is existed in the universe from the unity. The life in this world is from the unity". (5)

There is a global unit in Islam, based on the origins of monotheism. Islam, as being a social system is a practical way to make the assets of the unit in the emotional and intellectual life of mankind. The goal of the existence of such unity among the members of the community and the individuality of every individual and its movement within the unit is the establishment of that particular system, which is still lurking in the conscience of the universe. The life of the nation and its survival is also from the law of motion, but this law appears in the life of the nation in the urbanization, which is known in Islam by (Ijtihād): (diligence) means: (Individual Judgment). (Ijtihād): (diligence) is to uncover new stages, and their creation and invention in the fields of science and knowledge. If a stagnation or decline is found in the thought and diligence of the nation, the intellectual stagnation of its members becomes a graveyard for its high predestinations. Therefore, the thoughts, morals and high predestinations must be renewed to the survival of the nation and its immortality, because the life of the nation is related to the continued generating power of the thought. Iqbāl finds that Islam, as being a social movement believes in the moving perception, and rejects the rigid conception of the universe. The basis of life is on the spiritual predestination and basis of its immortality is on the diversity and change. The society, which is based on this basic perception, goes with the law of continuous changing necessarily. To organize the social life there must be some immortal assets and laws, because living in this variable universe can be only with those assets and laws. The fundamentalist movement, which follows the immortal law of the life, is called (Ijtihād): (diligence) in Islam. It should be noted that Iqbāl mentions this diligence (Ijtihād) by different names 
such as: a coup and movement in the sense of creativity, innovation, scarcity in the thought and movement towards the work. If there is no coup in the life, it is death originally, because the life spirit of Nations is the struggle for the coup.

Finally we say that the focus of his idea in the book (Reconstruction of the religious thoughts in Islam) is based on the principle of movement. All the objects are in a constant motion, so we hear sounds "Be" continuously, and the life is also moving. The Creator of the universe has a renewed significant, (every day He has a significance) then this movement is understood from the time, which is not circular, but straight to Iqbāl, he means that the history does not repeat its events, that who was yesterday, is not with us today, and that is with us today will not be with us tomorrow. Thus assets, provisions and principles are evolving towards the upgrading. (6) It is worthy to mention that Iqbāl does not want any change in which is the fixed in Islam, but wants the change in which fits for the changing, which is relevant to the requirements of worldly affairs, and the amendment can be by linking it with the contemporary sciences as being gained by the all human beings.

\section{B. Muḥammad Ḥusayn Haykal}

Muhammad Husayn Haykal also speaks with a confidence about the need of Western scientific movement, to make it fruitful for the thinking, reflecting on the all existence and on the human individual surrounded by all the means of prosperity and his relationship to this universe as the whole.

By this reconciliation between (the old inherited) and (the modern borrowed) can be a spark of inspiration manifested through the right word to explain the puzzle of existence for the people of the next generation, which is addressed by this word. (7) He says: "the universal word will come soon from our civilization and the West will accept it, and it will have a poetic inspired power derived from the reconciliation between (the old inherited) being as the (spiritual side) and (the modern borrowed), being as the (science)". So Haykal sees that the Creation can be by combining the spiritual heritage of the East and scientific findings of the West.

\section{Zaki Najib Maḥmūd}

He says: "Our renaissance after the false step of the civilization can only be achieved if incentives come from the religion and means taken from the science."... Incentives are values by their core... The values come from the religion. They are not things we can find out... They are pictures in front of the mind. We feel that we are charged to materialize these pictures in the affairs of ongoing life) (8)

If the Creation - to Muhammad Husayn Haykal - stems from the word of truth that have the power of persuasion and attraction, it is to Zaki Najib Mahmūd stems from an alive point of the view pushes its owner to the ways of daily practical life. (9) So revival of the heritage - to him - is that we have to open the windows to let the revival enter in our organic being, as it has a point of view which guide us in practical life (10), but we must be aware that this point of the view, although is only the view in the field of ideas, but it is linked to the work to Zaki Najib Mahmūd, so it is alive pushing its owner to the ways of practical life... He also emphasizes elsewhere, saying: So the orbit is the dynamic work... The thought and feeling comes from inside the solid works... If there is no work, there is no idea and no sense. Therefore, the Creation to Zaki Najib starts by the act actually, because the act is the basis for the appearance of the idea.

Those who go to the methodology of Western Orientalists to read the religious heritage of Islam one of them is Muhammad Arkūn and another one is Nașr 'Abu Zayd. We will explain the respective positions of each of them on the issue "Revival of Islamic Heritage".

\section{Muhammad Arkūn}

Muhammad Arkūn Explains the historical situation of Islam by the title: "Contemporary Islam". He says: There are several books speak naturally about Islamic Modernism or modern Islam or Islam in the face of modernity. All the books, as the whole, return as the time to the back until the nineteenth century (the beginning of Arab-Islamic Renaissance). The intellectuals of Renaissance have tried to apply some scattered pieces of their contexts separated from the European methodologies that have emerged during the modernity to the history of Muslim communities. They translated the European methodologies into their languages and transferred to their country, as for they could transfer or understand and absorb from them, but they cut off European thinking about the modernity from its natural context as they planted it in another context: which is the Arab-Islamic context. This transfer has received a little or a lot of success according to the intelligence of the authors. They have transferred essentially the historical methodology as it was prevailed in the nineteenth century at universities of Sorbonne, Berlin and Oxford... etc. It is the useful historical methodology in the investigation of ancient texts and manuscripts, but its time passed over now. Orientalists started clapping for successes of their senior students after they returned to their home countries to translate and teach the European science in the universities, but these successes were actually very percentile. I mean here by the senior students some personalities such as Ṭaha Hussein, Zaki Mubārak, Bishr Fāris and others like them. They imitated the methodologies of their 
teachers Orientalists and tried to translate and apply them to Arabic literature and Islamic heritage, but Islam and its heritage were not influenced or affected almost by these meager attempts. I mean that the application of these transferred methodologies from Europe did not affect the heritage in the depth and did not lead to a decisive impact on how to understand the religious heritage of Islam, because if it was so the current fundamentalist movements cannot be seen exploded with such force and violence. If the Arab-Islamic heritage was subjected to a comprehensive historical survey and a critical Lighting - comprehensive historical criticism could not be seen what happened later. This intuitive should be noted by the contemporary Arab intellectuals (and so in regards to Iranian, Turks and other Muslims intellectuals). If Islamic enlightenment was successful, the fundamentalism was not appeared and filled the street, home, school, university, every where and everything... If that intellectual modernity - even in its historical research form in the nineteenth century - had been able to break the traditional frameworks of thought, the spread of these extreme practices and obsolete discourses were not be able to be seen at the end of the twentieth century! (11)

The contemporary Islam knows that the political and social system of the traditional Islamic state was based upon the moral and jurisprudence - the legal values... These values are attacked and rejected everywhere, because it seems that these values are out of date and inappropriate for this age. So Muslims began to leave them if they could get a chance, because of the pressure of the modern world around them. (12)

In fact, the major religions, including Islam, formed always an interpretive, theological and doctrinal prosperous effectiveness in order to form the intellectual creativity of facilities for the beliefs and religious rituals, (see the size of the books in Qur'anic explanations, theology and jurisprudence!), but we note now a change in regards to the contemporary Islam or fundamentalist movements. This Islam is no longer interested in the evolution of that intellectual and explanatory effectiveness, as the classical Islam was interested in production, creativity and prosperity. As the political involvement, which is most important for the contemporary Islam, overcomes every other consideration, it overcomes the need of intellectual creativity of the facilities for the religious or ceremonial practice, also overcomes the primacy of the spiritual dimension leading to communicate with the absolute God. The current fundamentalist movements no longer think only about the power and authority, or anyhow to reach this goal. Here is the separation between them and the classical Islam, which has seen an amazing ideological pluralism among various Islamic sects of Sunni and Shiite, solitary and philosophers... Etc. As well as, the classical Islam was characterized by an openness of mind and thought on the high level, and by its great importance to the mystical spiritual experience. These characteristics are not found in the contemporary Islam at all.

Now Islam is a religion like other religions, Muslims are human beings like all other human beings and are not imprisoned in an eternal privacy or not bounded to anything else. The reader should know that Islam not a solid entity does not change or cannot be changed throughout the history. It has no eternal entity cannot be affected by anything, but affects everything as the fancy Muslim audience thinks. This is an ideal and nonhistorical perception about the things. They imagine that this ideal Islam is generated by the legislative foundational texts (Qur'an and Hadith) and prints all the communities with its character, in which it reached them and does not accept any modification or replacement by the time. We should know that the contemporary Islam is (as the classical Islam, as a newborn religion with the Qur'an and Muhammad the prophet, which is a product of the historical practice of humans, therefore it evolves and changes. It follows the historicity, like anything on the earth. It is produced by the historical practice done by the social factors have many differences and diversity from Indonesia (and Malaysia) to Iran to the maximum Morocco... It is also the result of an act of highly complex historical conditions across the time and place. For this reason we prefer to talk about hypostatic Islam, in the sense that Muslims have turned Islam into a huge hypostasis, which is capable of everything and affects everything without being affected by anything! The Western media turned it to a scary "bogeyman" not changed by a single hair since Muhammad the prophet until today... This kind of perception of Islam differs from its real historical perception. We should know that Islam, like any other religious or non-religious faith, is the product of the perceived forces that posed it as a doctrine ideologically. These forces are called today a force of populism; it is simmering people on the modalities of instincts, emotions and partisanship, it does not think by its own mind. (13)

There is only one Islamic revolution in the history, which is revolution of Muhammad, and beyond that every movement is a pale tradition and rigid support cannot bring any thing new. The appearance of Islam is considered as the preparation of a new history or the establishment of a new model unknown previously. The repetition of this Qur'anic discourse in the social circles - with many cultural and historical differences - and in the historical corners - with many various forms - is an evidence to prove that how this discourse is rich with its symbolized and transcendental idealism. As well as it is related to its high quality metaphorical composition, which has some multiple meanings and apply to many historical cases. The symbolic meaning is stronger and more fertile than the literal meaning. The language of Qur'an is a symbolic or metaphorical language generally. For this reason it has renewable meanings until now. What I am saying here about the Qur'an, certainly, applies to all the religious constitutional texts, like Bible and Torah for example. There is prophetic speech, which is 
characterized by the three religious books: Torah, Bible and Qur'an. This speech has a special language as its structure, which distinguishes it from others. For example, it distinguishes from the books of interpretation of Qur'an or books of jurisprudence built by Muslims later on these foundational books. So the language of interpreters of Qur'an, jurists, and speakers of dogmatic theology is not the language of Qur'an. The language of Qur'an is not as literal as it is like the free water flowing, explosive wonderful metaphor that catches the kernels. While the language of interpreters of Qur'an is an ordinary language, it is a realistic and literal language generally. (14) In the end of his words Muhammad Arkūn recorded three notes are as follows:

1. The system of thought that developed in the Islamic context since the appearance of Islam and until the end of the creative classical era all can be placed within the cognitive framework of medieval and ancient Greek. This means that all of the Arab-Islamic thought formed between 661 and $1258 \mathrm{AD}$ can be placed in the stage of pre-modernity in spite of all the philosophical creative production that leaded the classic stage: the stage influenced by Greek thought. This does not diminish its importance or greatness, but put it within its historicity, which indicates clearly that there is a long distance of the awareness of the time between the Arab-Islamic thought and modernity.

2. The study of this long period (from the thirteenth century until the nineteenth century) had been neglected for a long time. As they were talking about it superficially in the textbooks, saying it is the era of the decline or a long slumber or forgetfulness or conservative rigidity or the return to popular myths. Undoubtedly it contained all of that, but it needs a deep and comprehensive study, it is not suitable to call it the era of the decline and pass it as an unnoticed stone of the path as the authors usually do. Why it deserves all this attention? This is because the current Arab-Islamic societies are born from that era directly. Therefore we can not understand the current problems until we do not understand that period. (15)

In fact, there were two big breaks in the period of Ottoman caliphate, their impact was and still is on the Arab and Muslim world until today. The first was an internal and the second was external break. In the Ottoman stage Islamic thought became cut off form which was the best produced by Islamic thought itself in the classical stage, i.e. in the first six H. centuries of the history of Islam (until the death of Ibn Rushd in the late twelfth century). It is known that the classical period of Islamic history has been marked by the ideological pluralism, which had contributed to the fertility and prosperity of the classical period; which was totally neglected or forgotten after entering into the period called era of the decline (i.e. the first Seljuk and then the Ottoman II). Thus, we find that Muslims today are ignorant of the classical creative period, and thus they think that Islam is only this and nothing else ... The second break was with the outside world, i.e. Europe. The ArabIslamic thought slept and did not know what was happening around it from the scientific discoveries and philosophical developments. Thus the material and intellectual modernity, which was formed, had no link with the Muslim world, as it was not given any chance to contribute. Thus slept like the sleep of the people of the cave, and when they woke up in the early nineteenth century the modernity had completed a long distance to go forward. (16)

3. An intellectual and cultural movement emerged in the nineteenth century called the movement of "renaissance", tried to revive the precious heritage of classical stage; tried to resurrect it under the name "Heritage Revival" or identification of a new golden age of the history of Arab-Islamic civilization. Intellectuals of the renaissance have made their commendable efforts in this regard, but the problem was that the Renaissance came at a time when the breaks mentioned above had dug a very deep chasm between the revolutionary Europe having Enlightenment and lively movement, and Muslim communities debilitating after a long sleep, and because of the weakness of these communities and the long break from the movement of historical creativity, they were no longer able to take advantage of the mental tools inherited from the classical era (or the golden age) of Islam. Naturally, they had less capacity to take advantage of the positive historical science, which had been proposed by Orientalists in Europe between 1850 and 1940. It is well known that Orientalists had read and investigated some of the important texts of the Arab-Islamic heritage through a modern scientific way and published it for the first time in Leiden or Oxford or London or Paris or Berlin, etc. The Arab-Islamic societies had reached a bad situation of the weakness and degradation so that they no longer even able to interact with what was created by their own heritage before seven hundred years or even a thousand years. (17) 


\section{E. Nașr 'Abu Zayd}

Nașr 'Abu Zayd has divided the positions on the issue of Islamic heritage to three basic currents, namely:

1. First is current of those who say: "We now live a new era does not have any link to the past, not in the form of life or in the patterns of behavior, nor in the ways of thinking. They consider the (Heritage) as being their past with its good and bad, freedom and tradition, and rationality and myths. So the heritage with its rationality belongs to the past and fails to address the issues and problems posed by the life in its present form.

2. Second is current of those who make their slogan "Islam is the only solution". The distinction between (Islam) and (Heritage) to them pales largely because of ignoring theoretical emphasizing sometimes in the context of consideration generally -. There is a difference between (Heritage), which represents the achievement of mind of the social - historical human being in his perpetual attempt to bring the meanings of revelation to the ground of the reality and history. (Religion) in its basic original texts - as confirmed Imam 'Ali b. 'Abu Țālib - "does not speak by itself, but it is spoken by the men". The people deal with (the heritage) as a holy achievement should not prejudice only by the full respect and veneration and reverence. (18)

3. Third: is the current of (conciliation) as the mediator between current of the (break) and current of the (tradition). This central conciliator current compromises to the (falsification), by selecting the elements of thought derived from the different systems of thought, even conflicting sometimes to make a building by those different elements to be suitable for the present. The condition of selection to this current is based on the (utility) in the ideological sense, not in the cognitive sense, i.e. the idea is right as it is useful and not vice versa, means it is just correct because it is useful.

After mentioning these three positions Nașr 'Abu Zayd raises a question relates to what suits the era of globalization, says:

Is it possible to protect the heritage traditionally or instructively, with the situation of increasing weakness in the social structures to our intellectual trend in the age of globalization, which seeks to entangle the world and find some kinds of overall control?

Says: "This question needs to read the concepts of (time) and (history) and the relationship between both of them, at each of these three currents, because it seems that the current of (break) goes by the concept of time, which is separated between the (present) and (past) as a complete separation: as the three moments representing the (time) are three spaced moments, i.e. (the past) separates the (present), which is in its turn passing to be interrupted to generate (the future).

In contrast to this perception, it seems to him that the stream (Islam is the only solution) goes by the concept of time, considering the (present) a point of the decline and decay, and finds the fulfillment in the past, as the (present) must be built on the example of (past). If the (present) is re-built in accordance with the example of (past), the (future) will be safe.

The third reconciliatory current goes through the concept of time, considering the (present) a point of the meeting between the past and future, a point of interaction of experiences without any break or repeat, but the problem of this reconciliatory current is in its theoretical realization of the dialectical relationship between the moments of (the three times), which remains quite silent by an obsession of the past, i.e. the (Heritage) the most healthy and full of experience, and by an (other) obsession, i.e. the (West), which is the greedy identitythreatening colonial.

It seems to him that in each of these three currents the (heritage) has different features, because the (heritage) does not speak, but ideologies speak throughout the heritage.

Then he raises another question: how the heritage can speak, and how can we listen and improve our listening to the heritage?

He replies this question, saying: "The way to answer this question requires a changing in the (scientific) conditions to make the knowledge free of these conditions. Without changing these conditions, it is impossible for the heritage to become an area of the scientific and critical study, which finds the significance of the heritage in its social and historical context, and becomes able to distinguish between the level of contextual historical (meaning) and level of a general comprehensive (significance). This scientific study would reveal to us that the concept of (Heritage) should not be limited to the Islamic (Heritage), because even this (Islamic) heritage is a composited building, which belongs to pre-Islamic or non-Islamic layers and levels, are vary from one region to another region of the areas now in the geographical belt of the so-called Muslim world.

He confirms, saying: "The meaning of achievement of this scientific requirement is not to unmask once and for all levels of the (meaning) and (significance), as the search remains as an open horizon, with all the new achievement appears or the written text publishes, as well as the cognitive development, which does not be depended on the tools and research methodologies.

He believes that one of the most important elements of the challenge imposed by the imperialist colonial tide in the field of culture and thought is the element of (religion) by which (Islam) was accused that 
Islam is the main essential cause of the underdevelopment for the Muslim world. It is needless to say that this element: (religion) was also the component used to justify the Crusades, although it was in a different way. Here it is possible to distinguish between two types of the response to this challenge, as they both move in the same direction, despite the different nature of each. The same direction is seen in the acceptance, explicitly or implicitly, it is because of the conditional or sometimes reasonable relationship between Islam and the underdevelopment, and the difference in the nature of response is seen in the determination of intended meaning of the concept: (Islam), which is a reason of the retardation and its cause.

The religious reform movement in the Muslim world fundamentally has based on the basis of linking the backwardness to the misunderstanding of Islam by Muslims, denying that Islam as being a religion inspired from God is responsible of Muslims' backwardness. Hence the effort of reformers focused on providing a reading has an illuminated rational nature to the religious texts, aimed at ensuring the openness of religious meaning, to be able to absorb what seemed to them a new and useful in the European achievement. In order to achieve this goal the reading adopted a curriculum had a generally (selective nature) based on elements of rationality in the heritage, especially which was suitable to the level of European awareness adopted by Muslims of the renaissance, we can mention here in this context some names, like: Rifă'ah al-Ṭahțāwi, Jamal al-Din alAfghani, Muḥammad 'Abduh, Sayyid Aḥmad Khān, Muḥammad Iqbāl, Qāsim Amīn, 'Abdul Rāziq, Ṭāhā Hussein, and Al-Ṭāhir al-Ḥaddād, then Amīn al-Kholi, and Muhammad Aḥmad Khalf Allah, Maḥmūd Ṭāhā.

Thus Islamic awareness swallowed the taste of European discourse in explaining the reason of Muslims world' backwardness. Thus the concepts of (retardation) and (progress) associated with the religion as a strong relation in the structure of awareness, as it became impossible to break that relationship on this point.

Thus the religion became the only element for the recognition of cultural identity particularly, and the rest of the elements of this identity diminished to be disappeared.

As a result, the difference between Salafi currents and currents of the religious reform became a difference in the direction of the movement, not in its nature, while, the reformers focused their attempts to open the religious meaning to accommodate the developments and changes, Salafists focused their attempts to (restore) the essential constant religious meaning to build the community in accordance to that fixed meaning.

Here it is possible to understand the difference between the "restructure of the meaning" to accommodate the evolution has been done actually by the movement of history, and the "recast the reality" to suit the form on the constant eternal meaning. (19)

It is notable that Muhammad 'Abduh refers sometimes in some of his books to some signals reflecting a lack of correlation between the religion and the progress of society or its retardation. In his responses and discussions against (Hanoteau) - French Foreign Minister at that time and a representative of the stream of Western thought, which restricts the reasons for the backwardness of Muslims in their religion - Muhammad 'Abduh sees that Europe, which leads the secularism and the separation between the religion and state - also uses the religion as a weapon in its colonization against the Islamic world.

Clearly the awareness of Muhammad 'Abduh was involved in the defensive position about Islam basically, because his above mentioned phrase aims - in terms of the offense - denying the conditional correlation between (Islam) and (retardation). (20)

However, Nașr 'Abu Zayd believes that everyone of the extremists and moderates, agree that Islam has a constant complete meaning drafted by Muslim scholars and speakers of dogmatic theology before the age of decadence, i.e. in the fourth century $\mathrm{AH}$, as they exclude Islam from the drafting of the meaning by many philosophical, political and theological trends.

\section{Conclusion (Research Finding)}

We have studied some attempts done by some Muslim thinkers, reformers and rationalist innovators for the development of religious Heritage of Islam. Now it is clear that the development of heritage can not be done through the ready-made solutions from the continuous past, without any adjustment as the requirements of age, as well as we can not cut off our connection to our past in any way, but the development of heritage can be through the conciliation between the (constant) and (variable), as we see to Muhammad Iqbāl that the life has two faces, the constant face, which has the stability, and a moving variable and kaleidoscopic face, which is unstable. The first face is the doctrine of monotheism, and the second face is the image of diligence (Al-Ijtihād). Islam reconciled these two sides of life. In one hand Islam gave us some valuable, inclusive and comprehensive immortal assets and principles. We can be able to prove our feet in this changing world by them. In the other hand Islam gave us freedom to develop those assets and principles to build a healthy beneficial system through the diligence (Al-Ijtihād) in the light of those assets and eternal principles, as we see him saying that the life of Islamic religion is based on the mixing between the constant and variable. If Islam remains on this mixing, there will be the progress every moment.

It is notable that Iqbāl does not want any change in the constant in Islamic religion, so we can not change any thing in it, but Islam wants a changing in the variable thing, which has a relation to the requirements 
of worldly affairs. The amendment can be by linking the variable thing with the contemporary sciences, because they are obtained by all mankind.

We feel that there is such a desire to Muhammad Husayn Haykal, who wants to revive the religious heritage through the mixing between the old (tradition), which is (the spiritual side) and borrowed (the new), which is (the science). As well as we find such a desire to Zaki Najib. He says: "Our renaissance after the false step of the civilization can only be achieved if incentives come from the religion and means taken from the science."... Incentives are values related to their original core... The values come from the religion, which are not the things we can find out, but they are images in front of the mind. We feel that we are charged to materialize these images in the affairs of ongoing life".

If the Creation - to Muhammad Husayn Haykal - stems from the word of truth that has the power of persuasion and attraction, it stems to Zaki Najib Mahmūd from a point of the animate view pushes its owner to the ways in the daily practical life. So in his opinion, for the revival of Heritage we have to open the windows to let the revival enter in our organic body, as it has a point of the view, which guide us in the practical life. We must be aware that this point of the view, although is only the view in the field of ideas, but it is linked to the work to Zaki Najib, so it is an animate view pushes its owner to the ways of practical life... He also emphasizes elsewhere, saying: So the orbit is the dynamic work... The thought and feeling comes from inside the solid work... If there is no work, there is no idea nor any sense. Therefore, the Creation to Zaki Najib starts by the act actually, because the act is the basis for the appearance of the idea. These two pictures prove that the desired Heritage Revival (Creation) must be built not only by absorbing the heritage and digesting and inspiring its spiritual leading values and by understanding the Western scientific achievement and its investigation, but also primarily - on the authentic and distinct premises generated from these two, then the feeling will be produced by them, which soon will be transformed into an act, because the intellectual premises - Emotions - whether towards the heritage or the West will have a real value only if they turn into a practical point of the view, and are able to response with all the requirements and attitudes of our whole life. (28) The responses have their roots consciously and unconsciously in the time and place, and stand on a solid ground made by the ideas and needs of the present. Then the heritage and its creativity can be continued and the desired goal can be achieved.

Muhammad Arkūn feels that the contemporary Islam knows that the political and social system of the traditional Islamic state was based upon the moral and jurisprudence - the legal values... Now these values are attacked and rejected everywhere, because it seems that these values are out of date and inappropriate for this age. So Muslims began to leave them if they could get a chance, because of the pressure of the modern world around them.

He thinks that Now Islam is a religion like other religions. Muslims are human beings like all other human beings and they are not imprisoned in an eternal privacy or not bounded to anything else. The reader should know that Islam is not a solid entity does not change or cannot be changed throughout the history.

He also believes that there is only one Islamic revolution in the history, which is revolution of Muhammad, and beyond that every movement is a pale tradition and rigid support cannot bring any thing new.

He explained that the symbolic meaning is stronger and more fertile than the literal meaning. The language of Qur'an is a symbolic or metaphorical language generally. For this reason it has renewable meanings until now. He said that what I am saying here about the Qur'an, certainly, applies to all the religious constitutional texts, like Bible and Torah for example. There is prophetic speech, which is characterized by the three religious books: Torah, Bible and Qur'an. This speech has a special language as its structure, which distinguishes it from others. For example, it distinguishes from the books of interpretation of Qur'an or books of jurisprudence built by Muslim scientists later on these foundational books. So the language of interpreters of Qur'an, jurists, and speakers of dogmatic theology is not the language of Qur'an.

\section{Here, Muhammad Arkūn recorded three notes, as follows:}

1. The system of thought that developed in the Islamic context since the appearance of Islam and until the end of the creative classical era can be placed within the cognitive framework of medieval and ancient Greek.

2. The study of this long period (from the thirteenth century until the nineteenth century) had been neglected for a long time, saying that it is the era of the decline or a long slumber or forgetfulness or conservative rigidity or the return to popular myths. Undoubtedly it contained all of that, but it needs a deep and comprehensive study, it is not suitable to call it the era of the decline and pass it as an unnoticed stone of the path as the authors usually do, because the current Arab-Islamic societies are born from that era directly. Therefore we can not understand the current problems until we do not understand that period.

3. In fact, there were two big breaks in the period of Ottoman caliphate, their impact was and still is on the Arab and Muslim world until today. The first was an internal and the second was external break. In the Ottoman stage Islamic thought became cut off form which was the best produced by Islamic 
thought itself in the classical stage, i.e. in the first six H. centuries of the history of Islam. The second one was with the outside world, i.e. Europe. The Arab-Islamic thought slept and did not know what was happening around it from the scientific discoveries and philosophical developments. Thus the material and intellectual modernity, which was formed, had no link with the Muslim world, as it was not given any chance to contribute. Thus they slept and when they woke up in the early nineteenth century the modernity had completed a long distance to go forward.

He added that an intellectual and cultural movement emerged in the nineteenth century called the movement of "renaissance", tried to revive the precious heritage of classical stage, but the problem was that the Renaissance came at a time when the breaks mentioned above had dug a very deep chasm between the revolutionary Europe having Enlightenment and lively movement, and Muslim communities debilitating after a long sleep, and because of the weakness of these communities and the long break from the movement of historical creativity, they were no longer able to take advantage of the mental tools inherited from the classical era (or the golden age) of Islam. Naturally, they had less capacity to take advantage of the positive historical science, which had been proposed by Orientalists in Europe between 1850 and 1940. It is well known that Orientalists had read and investigated some of the important texts of Arab-Islamic heritage through a modern scientific way and published it for the first time in Leiden or Oxford or London or Paris or Berlin, etc. The Arab-Islamic societies had reached a bad situation of the weakness and degradation so that they no longer even able to interact with what was created by their own heritage before seven hundred years or even a thousand years.

As well as, Nașr 'Abu Zayd has divided the positions on the issue of Islamic heritage to three basic currents, namely:

1. First is current of those who say: "We now living a new era which does not have any link to the past, not in the form of life or in the patterns of behavior, nor in the ways of thinking.

2. Second is current of those who make their slogan "Islam is the only solution".

3. Third: is the current of (conciliation) as the mediator between current of the (break) and current of the (tradition). This central conciliator current compromises to the (falsification), by selecting the elements of thought derived from the different systems of thought, even conflicting sometimes to make a building by those different elements to be suitable for the present.

It seems to him that the current of (Islam is the only solution) goes by the concept of time, considering the (present) a point of the decline and decay, and finds the fulfillment in the past, as the (present) must be built on the example of the (past). If the (present) is re-built in accordance with the example of the (past), the (future) will be safe.

He believed that the religious reform movement in the Muslim world fundamentally has based on the basis of linking the backwardness to the misunderstanding of Islam by Muslims, denying that Islam as being a religion inspired from God is responsible of Muslims' backwardness. Hence the effort of reformers focused on providing a reading has an illuminated rational nature to the religious texts, aimed at ensuring the openness of religious meaning, to be able to absorb what seemed to them a new and useful in the European achievement. In order to achieve this goal the reading adopted a curriculum had a generally (selective nature) based on elements of rationality in the heritage, especially which was suitable to the level of European awareness adopted by Muslims of the renaissance.

Thus Islamic awareness swallowed the taste of European discourse in explaining the reason of Muslims world' backwardness. Thus the concepts of (retardation) and (progress) associated with the religion as a strong relation in the structure of awareness, as it became impossible to break that relationship on this point.

Therefore, the religion became the only element for the recognition of cultural identity particularly, and the rest of the elements of this identity diminished to be disappeared.

As a result, the difference between Salafi currents and currents of the religious reform became a difference in the direction of the movement. While, the reformers focused their attempts to open the religious meaning to accommodate the developments and changes, Salafists focused their attempts to (restore) the essential constant religious meaning to build the community in accordance to that constant meaning.

Here it is possible to understand the difference between the "restructure of the meaning" to accommodate the evolution has been done actually by the movement of history, and the "recast the reality" to suit the form on the constant eternal meaning. (21)

Here we note a similarity between Nașr Abu Zayd and Muhammad Arkūn, as they both do not ignore the past and historicity of the heritage, but they study the heritage in its environment and its time, then they get the significance of the meaning to open the way for a new age.

We believe that the feature (the interruption of civilization) is a hallmark of the intellectual and scientific heritage in Arab countries, which leads supporters of the heritage and its opponents both together to take wrong positions, and make them expect to see the heritage in such position that is not expected or to bind it with some reasons not related to it. (22) 
We can summarize the contrast between the perception of heritage, which leads to an intellectual progress and that view, which does not entail only the underdevelopment and say that the heritage in the first, lives through its death, whereas in the second it dies through its life. In the first the heritage has a connection without any interruption, so the result is that all the old stage paves the way for a new phase above it, which is absorbed by it, but the old stage overcomes and refutes. The heritage here is like the food for the developing body of knowledge. The growth of the body can be achieved only through the absorption of food, which lasts its existence in a certain sense, but lives and continues in other words - have the most important meaning - in the alive body. Secondly, when an outage occurs in the heritage, and when its revival is attempted, without realizing the requirements of the new era, which is occurred after the long discontinuity, in this revival there is a death for the heritage, because it will be motivated again at the wrong time, and will be sowed - such as the strange heart in a body of an age, so it must be rejected by the new era.

This means that the real revival of heritage can only be by passed and taken a ladder to further climb. In the fact, the revival of retrieval is to eliminate the heritage, which does not want us to store it like the buried treasure, which does not benefit any one, but wants us to exploit and spend it, so that we can get its benefit again and in a better form. When the storing of this wealth lasts too long, it must become the currency that make up this wealth non-current which is not viable for the benefit of any one. (23)

In the end, we have to recognize that Muhammad 'ābid al-Jābiri addressed the issue of Islamic heritage sincerely. He believed that the call for the reconstruction of Arab-Islamic thought or updating the Arab mind will remain just empty words without the first and foremost aim, which has to break the structure of the mind sloped to us from the era of decadence. The first thing must be broken through the strict criticizing, is its unchangeable and constant structure: (tradition of Aristotelian measurement) in its mechanical form, but in his opinion, he violates Muhammad Arkūn, who counts the passing the heritage on the way to the age of decadence just for transit a great mistake. It is true that we do not accept the traditional doctrines in Islam that violate the spirit of renewal, but we must not ignore the study of everything that reaches us from Islam's heritage, as well as the Arab-Islamic mind adopted Aristotelian measurement in the development of Arab-Islamic sciences, because if we reject those sciences, arts and literatures we will not find in our hands any thing from the Heritage to study it in its environment and its era, except which was investigated by the orientalists in Europe and published in Leiden or Oxford or London or Paris or Berlin, etc. because it is true that Islamic heritage was studied objectively and systematically by the orientalists in the West much more than the Middle East. It is known that the defect was not in Aristotelian logic, which was prevalent and valid approach in its time, but each doctrines represents the spirit of its time. Therefore Revival does not require that we cut the connection to the past, but we want to absorb the useful existing elements in the historicity of the past and be forward beyond that environment and age to create a new world.

However, we cannot support Salafist reform movement in the modern and contemporary Arab world. This movement was the mainstream and active more than any other movements in reviving and investing the heritage through a blatant ideological reading, based on the past, ignoring the ideological image of the "desired future", and then demonstrated that what had been achieved in the past can be achieved in the future. The Salafi religious movement raised the slogan of originality and adherence to the roots and the preservation of identity... The originality, roots and identity is understood as it is the Islam known by itself: (true Islam) not as the religion of Muslims (Islam).

So we will not support those who make their slogan "Islam is the only solution". The distinction between (Islam) and (Heritage) to them pales largely because of ignoring the theoretical emphasizing sometimes - in the context of consideration generally -. There is a difference between (Heritage), which represents the social - historical achievement of mind of the mankind in his perpetual attempt to bring the meanings of revelation to the ground of the reality and history.

We will also not support those who believe in the traditional understanding of the heritage, who read the heritage in its environment and time, but we feel that it should be studied for our environment and our time. Saying this we do not want to break with the heritage, but we want to link the heritage with the contemporary sciences.

We say: Yes to Muhammad Husayn Haykal, who speaks with a confidence about the need of Western scientific movement, to make it fruitful for the thinking, reflecting on the all existence and on the human individual surrounded by all the means of prosperity and his relationship to this universe as the whole.

Who says: By this reconciliation between (the old inherited) and (the modern borrowed) can be a spark of inspiration manifested through the right word to explain the puzzle of existence for the people of the next generation, which is addressed by this word. Who says: "the universe will come soon from our civilization and the West will accept it, and it will have a poetic inspired power derived from the reconciliation between (the old inherited) being as the (spiritual side) and (the modern borrowed), being as the (science)". So Haykal sees that the Creation can be by combining the spiritual heritage of the East and scientific findings of the West. 
We say: Yes to Zaki Najib Mahmūd, who says: "Our renaissance, after the false step of the civilization can only be achieved if incentives come from the religion and means taken from the science."... Incentives are values come from their assets, means the religion. They are not things we can find out... They are images in front of our mind. We feel that we are charged to materialize these images in the affairs of ongoing life.

As we find that if the creation - to Muhammad Husayn Haykal - stems from the word of truth that have the power of persuasion and attraction, it is to Zaki Najib Mahmūd stems from an alive point of the view pushes its owner to the ways of daily practical life.

We support Muhammad Iqbāl, who believed that the creation of a new world needs a new thinking that matching to the requirements of the present situation. If the requirements changed the thinking also must be changed, "because if the life is empty of a reversal, it is a death. The life spirit of the nations is the struggle for the reversal". He also stated in his words: "Do not hate the East, as well as, do not be away from the West, because the nature (the will of Creator: God) refers that you should light each dark night, whether it is in the East or in the West by the light of knowledge and faith, means by the word: "every dark night" the social, cultural and political situations of ignorant human societies everywhere in the world.

\section{References}

[1]. Muhammad Husayn Haykal: The New East, House of the knowledge, Cairo, 1978), p: 115, from an article in response to this trend titled (civilization of Middle East and its revival) has been published for the first time in "The politics weekly" 1928.

[2]. Zaki Najib Mahmūd: Renewal of the Arab Thought, Dār Al-Shurūq, Beirut, 1971, p, 592

[3]. Salahuddin Mohd. Shamsuddin: Islamic trend in the poetry of Muhammad Iqbal, Al-Dār Al-Salafiah, Bombay, 1991, p: 223-224

[4]. Muhammad Iqbal: (Kulliyāt / Persian), Iqbal Academy, Lahore, Pakistan.

[5]. Muhammad Iqbal: (Kulliyāt), Iqbal Academy, Lahore, Pakistan.

[6]. Magazine "Māh -e- Naw" a special issue on Muhammad Iqbal, the publications of Pakistan, Lahore, September, 1977

[7]. Muhammad Husayn Haykal: The New East, House of knowledge, Cairo, 1978, p: 115

[8]. Zaki Najib Maḥmūd: This era and its culture, Dār Al-Sharq, 1402 AH.), p: 249

[9]. Ibid, p: 82

[10]. Ibid, p: 85

[11]. Muhammad Arkoun: Issues in the criticism of the religious mind, translation and investigation: Hāshim Salih, Dār Al-Taliah, Beirut, the first edition, 1998, p: 170-172

[12]. Ibid, p: 173

[13]. Ibid, p: 175

[14]. Ibid, p: 176-177

[15]. Ibid, p: 194-195

[16]. Ibid, p: 195-196

[17]. Ibid, p: 196

[18]. Nasr Hāmid 'Abu Zayd: The discourse and interpretation, the Arab Cultural Center, First Edition, Beirut, 2000 , p: 180

[19]. Ibid, p: 188-189

[20]. Ibid, p: 193

[21]. Muhammad Ahmmad Hamdūn: Towards a theory of Islamic literature, Al-Manhal versions, Jeddah, Saudi Arabia, 1986, p: 60-61

[22]. Kamal Al-Yazigi and Emile Maalouf(Dr.): Selected articles from the literature, House of the science, Beirut, Lebanon, p: 69-71

[23]. Ibid, p: 71-72 